Hebrew Proper Names (1896) received very favourable notice, and brought him into the front rank of Hebraists. He contributed the commentary on Numbers to the "Temple Bible", and a more extensive treatise on the same book to the "International Critical Commentary"; to this latter series he also furnished a commentary on the first portion of Isaiah, and the completion of the very elaborate work on Job which the late Professor Driver had left unfinished at his death. These works embody the latest results of research and are characterized by painstaking thoroughness. Dr. Gray was greatly interested in Palestinian archæology, and contributed to the Quarterly Statement of the Palestine Exploration Fund, which he helped to administer. He also devoted some attention to that elusive subject, the Forms of Hebrew Poetry, on which he published a monograph.

In the Preface to his $J o b$, Dr. Gray acknowledged his obligations to Dr. Driver, whose influence in giving new directions to the study of his subject and founding a school with many distinguished representatives must have been as great as that exercised by any teacher of a literary subject. One who comes from the perusal of Dr. Pusey's Minor Prophets to the study of the commentaries composed by or under the influence of his successor finds himself in a new environment. The new school is justly commended for the attention which it devotes to archæology and in general for the sobriety of its conclusions.

D. S. M.

\title{
The Rev. John Drew Bate
}

The Rev. John Drew Bate was born in Plymouth in the year 1836, and by his death at a ripe old age the Society has lost one of its oldest and most valued members. He was sent to India by the Baptist Missionary Society in 1886, and, after a short stay in Eastern Bengal, was posted to Allahabad, where, earning the respect and affection of all classes of the com- 
munity, he laboured for nearly thirty years before his retirement in 1897. He became a member of the Asiatic Society of Bengal in 1873, and of this Society in 1881. This is not the place for describing his evangelistic work as a missionary, but a tribute must be paid in the pages of our Journal to his great knowledge of the people amongst whom he lived and of their language. With the latter he acquired an intimate familiarity, ripened by a sympathetic scholarship, and by his share in the translations of the Scriptures and by his other linguistic work he successfully carried on the tradition of learning which had been founded by his great predecessors in the same Missionary Society, Carey, Ward, and Marshman.

He is best known to Orientalists as the author of the Hindi Dictionary published in 1875, which is still the standard work on the language and has lately passed through a second edition. Some idea of the extent of his researches in connexion with this valuable work may be gathered from the fact that through his reading alone he was able to add no fewer than twentyfive thousand new words and forms of words that had not hitherto been explained. In regard to the width of his attainments, which were by no means confined to the language of the dictionary of which made him famous, I take the liberty of quoting the remarks of a most competent authority-a scholar who sat at his feet in Allahabad and who knew him well. In the Missionary Herald for March, 1923, the Rev. G. J. Dann writes :-

" His knowledge of the classical as well as the vernacular literature of India was great, especially of Muhammedanism, in which his learning was encyclopædic. Only one of the many volumes he wrote on this subject-Studies in Islam-was ever published. Publishers wanted only his scholarly researches, but Mr. Bate did not care to sacrifice his own purpose in writing, which was to help the missionary and the religious inquirer."

His later years were clouded by ill-health, which prevented him from taking an active part in our proceedings, and he 
passed peacefully away on the 26th January of this year. The only son who lived to man's estate became one of the sacrifices of the war, and every member of the Societyespecially those whose lot was cast in northern India-will extend their liveliest sympathy to his widow and her daughters in their latest bereavement.

G. A. G. 